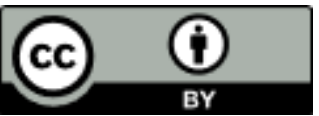

UDC 81'373.111=111

Original scientific article

Accepted for publication on 30.08. 2019

https://doi.org/10.29162/jez.2019.18

\title{
Frane Malenica
}

Lucija Žinić

University of Zadar

\section{Garden plants and butter knives - the effects of lexical and relation priming on nominal compound processing by native and non-native speakers of English*}

\begin{abstract}
Compounds are a frequent occurrence in the English language, but the way in which speakers, both native and non-native, process compounds is still a topic of discussion. Two factors have an influence on the recognition speed of compounds - lexical priming and relation priming. The former refers to faster recognition if a target and a prime compound share a common lexeme, while the latter refers to the inner relationships between modifiers and heads within a compound. The study conducted by Gagné \& Spalding (2004) shows a significant effect of relation priming on recognition of familiar compounds, while De Cat et al. (2015) report that highly proficient non-native participants use similar strategies for processing compounds as native speakers. The aim of this paper is to replicate these results by using sense-nonsense tasks with familiar compounds and native and highly proficient non-native participants to examine the effects of lexical and relation priming in these two groups. We hypothesize that the native speakers should provide faster reaction times and higher accuracy rates but that both groups would display similar facilitation effects with different types of primes, which the results of the study confirm.
\end{abstract}

Key words: compound processing; lexical priming; native and non-native speakers; noun-noun compounds; relation priming.

\footnotetext{
* The authors would like to thank Jana Willer Gold, Emilija Mustapić, and two anonymous reviewers for their helpful comments on earlier drafts of this paper.
} 


\section{Introduction}

English compounds have a rather straightforward structure - two or more lexemes are connected into a new form with its own new meaning and structure (Olsen 2000: 897-905). However, what is not immediately seen are the inner relationships between the constituents of a compound, the head and the modifier. At the most general level, compounds are divided into endocentric and exocentric, based on the broad relationship between the two constituents. Endocentric compounds, which are the main focus of this research, are characterized by the "presence of a head constituent" (Scalise \& Bisetto 2009: 54). The head carries both the grammatical and semantic functions of the compound while it is further specified by the first constituent, i.e. the modifier, hence straw in straw hat specifies a particular type of hat (Olsen 2000: 905-908).

The second dichotomy relevant for this paper is the one between root/primary and synthetic/deverbal compounds. The noun-noun (NN) compounds used in this research (e.g. marble table, linen napkin, flour sack) are primary in nature, i.e. their head constituents are not derived from a verb, as is the case with synthetic compounds (Roeper \& Siegel 1978; Selkirk 1982; Lieber 1983). Since the heads of these compounds are derivationally simple nouns (i.e. do not contain a verbal element), they do not invoke thematic relations within one another, as deverbal nouns do. Because of this property, their creation is less restricted, open to numerous interpretations and context-dependent (Lieber 1983: 260). For example, the noun oil can be modified by nouns like baby and olive, which invoke radically different semantic relations. The main focus of this paper are these inner relationships and factors that affect the recognition of this relationship, that is, the perception that native and non-native speakers of English have of the inner structures of compounds.

The research presented in this paper aims to analyse the factors that affect the processing of compounds. Specifically, our goal is to test whether compounds are processed faster when preceded by other compounds which share one of the component lexemes or by compounds with the same underlying semantic relationship between constituents. Another crucial question we explore is whether native and highly proficient non-native speakers of English employ similar strategies for processing compound nouns. In this paper, we will try to provide an answer to these questions using an experimental paradigm on endocentric noun-noun compounds chosen from the Corpus of Contemporary American English (COCA) (Davies 2008).

Our paper is structured as follows: Section 2 will summarize previous theoretical and empirical studies which deal with theoretical models of noun-noun com- 
pounding and their processing and provide a brief overview of studies that compare the processing of morphologically complex words among native and non-native speakers. This will be followed by research questions and aims, which were inspired by Gagné \& Spalding's (2004) study. In Section 3, the methodology and design of this study will be explained. In the fourth section, we compare the data obtained from native and non-native participants and we analyze the results of each group separately. Finally, a tentative conclusion to this study will be given in the final section with some indications for further research.

\section{Previous studies on compound relations}

\subsection{Theoretical models of relations in compounds}

At the most general level, the formation pattern for English compounds can be expressed as a schema in (1) in which $a$ and $b$ represent lexical categories (Booij 2009), nouns in case of NN compounds. Form-wise, this schema is quite straightforward - two lexical items (nouns) are conjoined and the right one determines the word class for the whole compound (morphosyntactic head) and the type of entity referred to by the compound (semantic head). However, the vagueness of the relation $R$ that holds between the constituents $a$ and $b$ has remained a puzzle that many linguists have tried to solve in different ways.

[[a]X [b]Yi]Y ' $Y i$ with relation $R$ to $X$ '

Lees (1960) represents one of the earliest attempts to analyse the structure of compounds through the scope of semantic relations of their constituents. The core of his idea is that the relations between two members of a compound are parallel to relations which hold between sentential constituents such as subjects, predicates, direct objects, middle objects, prepositional objects, etc. (1960: 125). Lees claimed that compounds are derived from sentences via series of transformational operations which take place and gradually transform a sentence (2a) into a compound (2e) (1960: 145).

(2a) The well yields oil.

(2b) ...well which yields oil...

(2c) ...well yielding oil...

(2d) ...oil-yielding well...

(2e) ...oil well... 
Frane Malenica - Lucija Žinić:

Garden plants and butter knives - the effects of lexical and relation priming on nominal compound processing by native and non-native speakers of English

While theoretically elegant and appealing, Lees's proposal had several major drawbacks, which Downing (1977: 811) neatly summarizes as "arbitrariness of underlying structures" and "the irrecoverable deletion of meaningful material". The crux of this criticism comes down to arbitrariness on both ends - a compound could be aptly described by using several relationships, which makes its inclusion in one category instead of the other rather arbitrary. On the other hand, assuming that compounds like oil well and car thief are both derived from underlying sentences through deletion of phonological material ignores the fact that the relationship between the constituents in them is radically different and yet no material is left to signal this difference in relationship. ${ }^{1}$

In her study of Complex Nominals (CNs), Levi (1978) assumes a similar position to Lees (1960) in terms of syntax being the main accomplice in the derivation of CNs. Her system, however, places a more severe constraint on the formation of CNs by limiting them to derivation from either sentences or Noun Phrases in the underlying structure by deletion of Recoverably Deletable Predicates (RDPs) CAUSE, HAVE, MAKE, BE, USE, FOR, IN, ABOUT, and FROM (Levi 1978: 50). She admits that while "it cannot be denied that there are idiosyncratic aspects to the grammar of complex nominals, these involve factors such as lexicalization, individual variation [...], historical remnants in contemporary English, and a certain analytic indeterminacy [...]" (Levi 1978: 52), "complex nominals are formed by grammatical processes whose regularities and complexities are amenable to systematic linguistics analysis in terms of both syntactic and semantic properties" (Levi 1978: 51). ${ }^{2}$ Thus, her analysis focuses on those compounds which represent open-ended classes in the English language, i.e. those produced by synchronically productive processes, with the aim of constructing a theory capable of associating all compound forms with the entire range of their possible meanings. This range of possible meanings and the potential ambiguities between them are limited by pragmatic and semantic factors (1978: 50-52). Table 1 provides a summary of Levi's RDPs and the compounds which exemplify them.

Levi's proposal represents a step forward in the sense of providing a basis for a systematic study of formation of compounds as the number of potential relationships is limited by the number of predicates. Unfortunately, this has the potential of leading to ambiguity within the same predicate, as noted by Downing (1977).

\footnotetext{
${ }^{1}$ A more detailed critique of Lees's work can be found in Downing (1978) and ten Hacken (2009).

${ }^{2}$ Lexicalization is also analyzed as a potential factor for compound stress assignment by Plag et al. (2008).
} 
Table 1. Recoverably Deletable Predicates and their examples (from Levi 1978: 76)

\begin{tabular}{lll}
\hline RDP & $\mathrm{N}_{1}>$ direct object of relative clause & $\mathrm{N}_{1}<$ subject of relative clause \\
\hline CAUSE & tear gas & drug deaths \\
HAVE & picture book & government land \\
MAKE & silkworm & snowball \\
USE & voice vote & $/$ \\
BE & soldier ant & $/$ \\
$\mathrm{IN}$ & morning prayers & $/$ \\
FOR & horse doctor & $/$ \\
FROM & olive oil & $/$ \\
ABOUT & tax law & $/$ \\
\hline
\end{tabular}

The compounds headache pills and fertility pills would both be classified under the predicate FOR, but there is an obvious difference in meaning between the two.This indicates that some of Levi's categories might be too vaguely defined or that the meaning of compounds cannot be exhaustively expressed through sentential paraphrases (Downing 1977: 814-815), which is why her analysis should be taken as a loose guide.

A position similar to Levi's is also taken by Jackendoff $(2009 ; 2010)$, who operates within Parallel Architecture, a framework similar to Construction Morphology (Booij 2010) in the sense of being situated between the two extremes represented by the mainstream generative models and Langacker's (1987) Cognitive Grammar (Jackendoff 2009: 107). Like Levi (1978), Jackendoff also recognizes the importance of the productive facet of compound formation - while some compounds are stored as single lexical entries, there need to be some principles of their creation and parsing. Still, these principles are not the same as those for syntax since compounds require additional support in terms of discourse and extralinguistic context. ${ }^{3}$ The evident expressive power and simplicity of English NN compounds seem evidence enough for Jackendoff to regard compounds as remnants of what Bickerton (1990) calls "protolanguage" - an earlier step in the evolution of language, which

\footnotetext{
${ }^{3}$ In fact, Jackendoff, citing Ryder's (1994) study in which the participants were asked to provide the interpretation of novel compounds, claims that the interpretations produced for novel compounds like giraffe land (e.g. 'a giraffe on land') seem to indicate that native speakers are more concerned with plausibility than with rules of grammar when forced to produce an interpretation of a nonce form.
} 
Frane Malenica - Lucija Žinić:

Garden plants and butter knives - the effects of lexical and relation priming on nominal compound processing by native and non-native speakers of English

had vocabulary and pragmatics but no or very little syntactic and morphological rules. $^{4}$

His classification of NN compounds works in two steps - determining the head (in English, this is typically the second noun, or $\mathrm{N}_{2}$ ), and establishing the semantic relation between the head and the non-head noun $\left(\mathrm{N}_{1}\right)$. At a general level, $\mathrm{N}_{1}$ can be either an argument of $\mathrm{N}_{2}$ (as is the case in synthetic compounds, such as truck driver, shoemaker, etc.) or its modifier (as is the case in root compounds, such as beer bottle, raincloud, etc.). For the latter case, Jackendoff (2009; 2010) proposes a set of most prominent functions (Table 2), much akin to the one proposed by Levi (1978).

Though some differences between categories may be noted between Table 1 (Levi 1978) and Table 2 (Jackendoff 2009), these two classifications share the same underlying logic and there are even some overlaps between the categories they propose. For example, the predicate MAKE is equivalent to the function MAKE; the predicate FROM is equivalent to the function COMP.

Table 2. Functions of English compounds and their examples (from Jackendoff 2009: 123-124)

\begin{tabular}{|c|c|c|}
\hline Function & Meaning & Example \\
\hline $\operatorname{CLASSIFY}\left(\mathrm{N}_{1}, \mathrm{~N}_{2}\right)$ & ' $\mathrm{N}_{1}$ classifies $\mathrm{N}_{2}$ ' & beta cell \\
\hline $\mathrm{N}_{2}\left(\mathrm{~N}_{1}\right)$ & ' $a$ /the $N_{2}$ of/by $N_{1}$ ' & sea level \\
\hline $\operatorname{BOTH}\left(\mathrm{N}_{1}, \mathrm{~N}_{2}\right)$ & 'both $\mathrm{N}_{1}$ and $\mathrm{N}_{2}$ ' & boy king \\
\hline SAME/SIMILAR $\left(\mathrm{N}_{1}, \mathrm{~N}_{2}\right)$ & ' $\mathrm{N}_{1}$, and $\mathrm{N}_{2}$ are the same/similar' & piggy bank \\
\hline $\operatorname{KIND}\left(\mathrm{N}_{1}, \mathrm{~N}_{2}\right)$ & ' $\mathrm{N}_{1}$, is a kind of $\mathrm{N}_{2}$ ' & puppy dog \\
\hline SERVES-AS $\left(\mathrm{N}_{2}, \mathrm{~N}_{1}\right)$ & ' $\mathrm{N}_{2}$ that serves as $\mathrm{N}_{1}$ ' & extension cord \\
\hline $\operatorname{LOC}\left(\mathrm{N}_{1}, \mathrm{~N}_{2}\right)$ & ' $\mathrm{N}_{2}$ is located at/in/on $\mathrm{N}_{1}$ ' & tree house \\
\hline $\mathrm{LOC}_{\text {temp }}\left(\mathrm{N}_{1}, \mathrm{~N}_{2}\right)$ & ' $\mathrm{N}_{2}$ takes place at time $\mathrm{N}_{1}$ ' & spring rain \\
\hline $\operatorname{CAUSE}\left(\mathrm{N}_{1}, \mathrm{~N}_{2}\right)$ & ' $\mathrm{N}_{2}$ caused by $\mathrm{N}_{1}$ ' & diaper rash \\
\hline $\operatorname{COMP}\left(\mathrm{N}_{2}, \mathrm{~N}_{1}\right)$ & ' $\mathrm{N}_{2}$ is composed of $\mathrm{N}_{1}$ ' & rubber band \\
\hline $\operatorname{PART}\left(\mathrm{N}_{1}, \mathrm{~N}_{2}\right)$ & ' $\mathrm{N}_{2}$ is a part of $\mathrm{N}_{1}$ ' & apple core \\
\hline \multirow[t]{2}{*}{$\operatorname{MAKE}\left(\mathrm{N}_{1}, \mathrm{~N}_{2}\right.$ FROM Z) } & ' $\mathrm{N}_{2}$ made by $\mathrm{N}_{1}$ ' & moonbeam \\
\hline & ' $\mathrm{N}_{2}$ made from $\mathrm{N}_{1}$ ' & apple juice \\
\hline \multirow[t]{2}{*}{$\operatorname{PROTECT}\left(\mathrm{N}_{1}, \mathrm{~N}_{2}\right.$ FROM Z) } & ${ }^{\prime} \mathrm{N}_{2}$ protects $\mathrm{N}_{1}$ ' & chastity belt \\
\hline & ' $\mathrm{N}_{2}$ protects from $\mathrm{N}_{1}$ ' & flea collar \\
\hline
\end{tabular}

\footnotetext{
${ }^{4}$ For a more detailed view of this, see Jackendoff (2009: 111-114) and Jackendoff \& Wittenberg (2014).
} 
While Levi's (1978) taxonomy represents the basis for the analysis presented in Gagné \& Shoben (1997), Gagné (2002), Gagné \& Spalding (2004), Gagné et al. (2005), whose results our paper aims to replicate to an extent, we assume similar results would apply had these studies been based on Jackendoff's categories.

\subsection{Empirical approaches to relations in compounds}

Whereas the taxonomies in Levi (1978) and Jackendoff (2009) explain the derivation of compounds through a finite set of categories or predicates, Downing's (1977) paper lies on the other end of the spectrum and it also represents one of the first experimental approaches to the study of compounds. ${ }^{5}$ Downing considers misguided any attempt to provide a finite list of sentential relations which would explain the totality of compound relations. In turn, she places emphasis on pragmatic factors, such as name-worthiness of referents (Downing 1977: 814-815). In a sense, one cannot but agree with her - while there seems to be some correspondence in relations holding between sentence constituents and compound constituents, this does not necessarily imply that one is derived from the other. However, taking her position to the extreme and assuming that their formation is completely situation-dependent would ignore their near infinitely productive potential and assume all compounds are stored as single lexical items and not as productive patterns, which does not seem to be supported by empirical data. Thus, some sort of categorization system should be assumed to exist, but not necessarily one based on syntactic constraints.

This is the stance assumed in one strand of psycholinguistic approaches to the study of compounds, such as those by Gagné and her colleagues. Of course, the issue of compound processing leads to a much bigger question within morphology and psycholinguistics - whether or not speakers parse morphologically complex words into their constituents. The idea that complex words are parsed into morphological constituents can be traced back to the seminal study by Taft \& Forster (1975), who found priming effects for prefixed words. ${ }^{6}$ However, as Ji et al. (2011: 407) report, it is assumed that morphological decomposition is a more costly strat-

\footnotetext{
${ }^{5}$ Of course, additional possibilities were proposed in other works, such as Selkirk (1982) and Lieber (1983), who attempt to derive the meaning of all root compounds from rules of syntax, or Kay \& Zimmer (1990 [1976]), who are rather sceptical about the possibility of finding a finite set of compound relations. We do not consider these approaches here for the sake of brevity, but the reader is referred to them for an alternative view.

${ }^{6}$ For a more detailed review of the history of these questions and the potential future avenues of research, cf. Gagné (2009), Gagné \& Spalding (2010), and Marslen-Wilson \& Tyler (2007).
} 
Frane Malenica - Lucija Žinić:

Garden plants and butter knives - the effects of lexical and relation priming on nominal compound processing by native and non-native speakers of English

egy for parsing morphologically complex words in comparison to the direct access (i.e. full storage), despite the fact that decomposition is a widely reported effect. In their experiments, Ji et al. (2011) compare the processing of compounds with that of monomorphemic words and analyse the effects of semantic transparency on processing load. The results they present indicate that access to lexical entries of compound constituents might have a facilitatory effect on processing. In a similar vein, the study conducted by Murphy (1990) shows priming effects of modifiers in noun phrases, particularly in those cases when the adjectives functioning as modifiers expressed features easily relatable to the noun's schema (cold beer vs. hot garbage) and when provided in a meaningful context (1990: 282-283). The studies of Dutch compounds by Sandra (1990; 1994) and Zwitserlood (1994) showed that semantically transparent compounds ${ }^{7}$ are decomposed rather than stored as individual units in the lexicon. Similar effects were obtained for English compounds by Gagné \& Shoben (1997). They found that the relational availability (operationalized as the frequency of this relation appearing for a particular constituent) of the first, nonhead compound constituent had a significant effect on sense-nonsense judgements, but, interestingly enough, they do not find a similar effect for the head constituents (1997: 80). ${ }^{8}$ In a study conducted using magnetoencephalography (MEG), Fiorentino \& Poeppel (2007) also provide strong indications for morphological parsing, and also report the length, frequency, and syllabicity as features of the constituents which might be the source of the effect.

Libben et al. (1999) looked at parsing strategies for ambiguous compounds like clamprod, which could be interpreted either as clamp rod or clam prod. Their results indicate that parsing was primarily based on the plausibility of meaning of each parse, which is, interestingly enough, in line with what Jackendoff (2009) claims (cf. footnote 3 above). Schmidtke et al. (2016: 557) regard this as a strong argument for semantic effects in the processing of morphologically complex words. On a similar note, Coolen et al. (1991) come to the conclusion that interpretability of compounds can be attributed to two factors - appropriateness of a small set of basic semantic relations, and availability of familiar lexicalized compounds with semantically related nouns. The first factor is related to the concept of entropy, which Schmidtke et al. (2016) find crucial for analysis of competing relations. According to Coolen et al. (1991), highly interpretable compounds tend to include a

\footnotetext{
${ }^{7}$ And semi-transparent compounds, according to Zwitserlood (1994).

${ }^{8}$ To rule out the possibility that modifiers have a stronger effect on account of appearing first in a compound, Gagné \& Spalding (2010: 485) cite studies which find the same effect of non-head constituents conducted on compounds in languages in which the non-head constituent is the second element.
} 
smaller set of basic relations and a smaller proportion of potential idiosyncratic paraphrases, which means lower levels of entropy. As availability of familiar relations is affected by both general usage and recent usage (Schmidtke et al. 2016), it can be analysed via two different methods - corpus frequencies and the priming paradigm. Recent usage affects the processing of lexicalized compounds in such way that compounds preceded by primes with the same semantic relation tend to have quicker response times in lexical decision tasks or sense judgements (Gagné $\&$ Spalding 2004). However, as Schmidtke et al. (2016) claim, it might not necessarily be the case that the same relations within the priming paradigm have a facilitatory effect, but that different relations actually have a competing effect.

The research presented in Gagné \& Spalding (2004), which we attempt to replicate in this paper, looked at the difference between the effects of repetition priming and relation priming on modifiers in familiar, lexicalized compounds. Both experiments presented in their paper examined the reaction times for nominal compounds when preceded by a compound with the same first constituent and the same relation (eardrops - earrings), the same constituent and a different relation (earhole-earrings), or with a different constituent and a different relation (toothpaste - earrings). ${ }^{9}$ The only difference between the two experiments is that the first one asked the participants to provide sense/nonsense judgements, while the second used a word/non-word task. The results show the effects of both repetition and relation priming in the word/non-word task (Gagné \& Spalding 2004: 482-483), and in the sense/nonsense task, which is used in our experiment.

\subsection{Differences in processing between native and non-native speakers}

The issue of processing by native and non-native speakers has attracted a lot of attention in recent years (inter alia, Conklin \& Schmitt 2008; Feldman et al. 2010; Clahsen \& Neubauer 2010; Diependaele et al. 2011; Siyanova-Chanturia et al. 2011; De Cat et al. 2014; 2015; González Alonso et al. 2016), but the results do not seem to be unidirectional. ${ }^{10}$ Siyanova-Chanturia et al. (2011) found that native and non-native speakers differ in terms of speed of processing idioms and novel phrases. Specifically, while native speakers process idioms faster than novel phrases, the same does not hold for non-native speakers, who process novel phrases

\footnotetext{
${ }^{9}$ A similar experiment can be found in Gagné (2002) in which semantically related primes were used instead of repeated constituents. Much like Gagné \& Shoben (1997), this paper also reports statistically significant results of relation priming only for non-head constituents.

${ }^{10}$ For a more in-depth discussion, see Feldman et al. (2010) and González Alonso et al. (2016) and references therein.
} 
Frane Malenica - Lucija Žinić:

Garden plants and butter knives - the effects of lexical and relation priming on nominal compound processing by native and non-native speakers of English

faster. In their study of native and non-native processing of complex words in German, Clahsen \& Neubauer (2010) found different interactions of surface frequency and stem-priming effects among the two groups. They report a strong surface-frequency effect and no stem-priming effect among the non-native speakers of German and a combination of surface-frequency and stem-priming affect among the native speakers, which for Clahsen \& Neubauer (2010: 2634) indicates that non-native speakers rely more on the whole-word storage strategy instead of decomposition, in comparison to native speakers.

Contrary to this view, Feldman et al. (2010) report morphological facilitating effects for verb inflections in masked prime and cross-modal priming experiments, conducted among both native and non-native participants. However, while their native speaker data show a difference in RT between morphological (billed-bill) and orthographic (billion-bill) priming, the non-native participants produced equivalent facilitation effects for both types of prime in comparison to the baseline (unrelated) condition. Diependaele et al. (2011) find that processing of morphologically complex words functions along the similar lines for native and highly proficient nonnative participants. Since they base their results on data from highly proficient nonnative participants, they claim that any differences in processing between native speakers and less proficient L2 speakers of English "[...] reflect an intermediate state in the transition towards the target (L1) architecture rather than a fundamentally different way of handling native and non-native language input" (Diependaele et al. 2011: 356). This perspective on the development of linguistic proficiency among the non-native speakers is consistent with our view in this paper as well. The study on synthetic compounds by González Alonso et al. (2016) also provides robust evidence of morphological priming among both native and non-native participants. While their native and non-native speakers differed in terms of RT and accuracy, they patterned similarly to different types of priming and showed almost identical use of morphological structure. Both groups showed facilitation effects when the target word was primed by a morphologically related word (fundfundraiser) and no effect when the target was primed by an orthographically related word (funk-fundraiser) in comparison to the baseline condition. Stekauer (2005) also finds significant degree of agreement in identifying predictable readings between native and non-native participants, although his comparison of the two groups is based on offline measures.

De Cat et al. $(2014 ; 2015)$ examined the processing of compounds with native English speakers and two groups of non-native speakers - German and Spanish. The difference between the two non-native groups proved to be important as compounds in German are right-headed and productive (as in English), while com- 
pounds in Spanish are left-headed and not productive. This difference was reflected in accuracy rates and was taken as an indication that L2 processing can be inhibited by L1 factors, despite the acquisition of intended form and meaning (De Cat et al. 2015: 13). Overall, De Cat et al. (2015) find that highly proficient non-native speakers use the same processing strategies for transparent NN compounds as native speakers, which represents an important finding for our study.

In very general terms, decomposition of transparent $\mathrm{NN}$ compounds by native speakers requires two related processes - recognizing the meaning of each constituent and then establishing a meaningful connection between the constituents (Jackendoff 2009; Lee 2011). If the processing of compounds by highly proficient non-native speakers operates on the same principles (as De Cat et al. 2015 and González Alonso et al. 2016 suggest), this would represent an important implication not just for the study of compounds, but for the overall theory of grammar. If native and non-native speakers display the same effects when processing morphologically complex words (affixed words or compounds), this could be taken as an indication that complexity in the morphological domain (and any other linguistic domain for that matter) is not pre-determined by innate factors but is a result of an incremental input-based development. This question, however, is far beyond the scope of this study.

In terms of the present study, we expect the native participants to provide faster reaction times and higher accuracy rates than non-native participants, in line with all previous studies on morphological processing. In line with Gagné \& Spalding (2004), we would expect the native participants to show both relation and lexical ${ }^{11}$ priming effects. In terms of non-native participants, we would expect them to be similarly affected by different priming types as native participants.

\subsection{Towards the present study}

In light of the discussion on native and non-native processing, the aim of our research is to partially replicate the results of Gagné \& Spalding (2004) with nonnative participants as an additional group. Given the overall issues with replicability in social sciences in recent years (cf. Pashler \& Wagenmakers 2012 and references therein), we feel that replicating this research and possibly extending its results to non-native English speakers would confirm the strength of the original

${ }^{11}$ Gagné \& Spalding (2004) use the term repetition priming for this type of priming, but nothing hinges on this terminological preference. 
Frane Malenica - Lucija Žinić:

Garden plants and butter knives - the effects of lexical and relation priming on nominal compound processing by native and non-native speakers of English

findings, add new valuable insights to the field, and hopefully stimulate further similar research. ${ }^{12}$

However, several minor modifications were made to the methodology used by Gagné \& Spalding (2004), in order to explore additional aspects of processing NN compounds. Since the taxonomies of relations in compounds as proposed by Levi (1978) and Jackendoff (2009) are intended to capture generalizations over potentially infinite sets of compounds, we find that better insights into the nature of these relations might be obtained by focusing on non-lexicalised compounds instead of lexicalized ones. The compounds we decided to use as stimuli in our study were frequent enough to be familiar to all participants, which was confirmed by a separate procedure (cf. Section 3.1.). However, they cannot be regarded as examples of lexicalized compounds, as reflected in their relatively low frequency and spelling (cf. Plag et al. 2008).

The second difference between our paper and Gagné \& Spalding (2004) is that Gagné \& Spalding do not include a condition which involves relation priming without lexical priming, which we do include in our experiment. We use this condition to assess whether relation priming has any effect at all when functioning without repetition priming, and, in case it does, to test whether the effect of relation priming is stronger than that of repetition priming. The third difference between these two studies is the number of items. As can be seen in Section 3, a total of 36 target compounds was used in our experiment, while Gagné \& Spalding (2004) used 84 target compounds. We opted for a shorter experiment so as to avoid participant fatigue, but as we shall see in Section 4, this might have come at the cost of a statistically significant difference (and lack thereof) between particular categories. ${ }^{13}$ Apart from the differences described in the paragraphs above, the methods used in our study were identical to those in Gagné \& Spalding (2004), in order to ensure the validity of our replication.

In light of the research conducted by Gagné \& Spalding (2004) and the studies mentioned in Section 2.3., we intend to answer the two questions presented in the introduction. Specifically, we want to investigate whether native and non-native speakers' speed of recognition of familiar compounds changes when relation priming or repetition priming are involved and whether there is a difference in pro-

\footnotetext{
${ }^{12}$ This need for replication studies is also reflected in De Cat et al. (2015) regarding their work on NN compounds.

13 As we shall see in Section 4.1. and Section 4.2., our data show a significant effect for type of prime, but the post hoc analysis does not show statistically significant results for all priming combinations, which we attribute to a relatively low number of data points.
} 
cessing between native and highly proficient non-native speakers of English. In terms of the first question, we want to see whether a common underlying relationship has a stronger impact on the speed of recognition/retrieval than lexical relatedness of compounds, i.e. whether a compound like water bottle (i.e. bottle FOR water) is recognized faster when it is preceded by a compound with the same underlying relationship like wine glass (glass FOR wine), or when it is preceded by a compound with a common lexeme but a different underlying relationship like $w a-$ ter vapour [vapour FROM water]. Additionally, we want to check whether the individual modifier-head relations like [noun MADE OF modifier] (e.g. metal door, pumpkin pies, crystal vase), [noun FOR modifier] (e.g. water tank, cigar box, sugar bowl), and [noun IN modifier] (e.g. village school, prison yard, river stones) have an effect on reaction time. Some of these relationships, like [noun MADE OF modifier], could perhaps be perceived as more common than others, e.g. [noun FOR modifier] or [noun IN modifier] and vice versa, which ultimately might influence the recognition process. Given that Shoben (1991) and Gagné \& Shoben (1997) found no difference in processing complexity between these modifier-head relationships, we expect our study to be consistent with these results.

Our study aims to replicate the results of Gagné \& Spalding (2004) in terms of obtaining relation and lexical priming effects for English NN compounds and see whether similar results could be obtained with highly proficient non-native participants, in line with De Cat et al. (2015) and González Alonso et al. (2016). The reasons for replicating these results are manifold - replication of experimental results from Gagné \& Spalding (2004) using a different set of stimuli and participants would strengthen the claim about the effects of relation priming on processing of compounds and represent a good indication that conceptual factors do indeed play a role in morphological processing. Obtaining a similar effect with highly proficient non-native speakers would also provide valuable insights into the extent of these effects and the strategies employed by non-native speakers, and would represent an interesting finding for the more general questions about the acquisition of grammar.

A further question which we want to answer in this paper is related to the frequency of compounds. The issue of frequency effects on compound processing was pursued in Gagné \& Shoben (1997), and it was operationalised as the frequency of occurrence of the head or the modifier within a particular relation. However, since our study deals with familiar compounds, we decided to look at the interaction of frequency on processing at the level of the entire compound, not its individual constituents. Although we initially aimed to use compounds with similar normalized frequency, balancing compounds across relations, number of syllables and frequen- 
Frane Malenica - Lucija Žinić:

Garden plants and butter knives - the effects of lexical and relation priming on nominal compound processing by native and non-native speakers of English

cy turned out to be too restrictive as some compounds were over almost 70 times more frequent than others (e.g. body parts has a normalized frequency of 3.182 and garden plant has a normalized frequency of 0.046). Thus, we decided to loosen this criterion and conduct an additional analysis of a possible correlation between normalized frequency and reaction times.

\section{Methodology and design of the experiment}

The data for this experiment were collected in two phases. Firstly, the compounds that were used in the experiment were collected from the Corpus of Contemporary American English (COCA). The lists of chosen compounds were then given to students of English from the University of Zadar in order to test if the selected ones are known to them. In the second phase of research, the experiment was conducted with two groups of participants - native English speakers and non-native students of English.

\subsection{Corpus search and material}

Our compounds were obtained from COCA (Davies 2008). We selected those compounds whose heads denote concrete and material objects, not abstract entities. The words thus retrieved were filtered according to syllable number (two-syllable words for modifiers and one-syllable words for heads) and modifier-head relation (noun MADE OF modifier, noun IN modifier, noun FOR modifier). The compounds were grouped into categories based on the most plausible interpretation of the modifier-head relations. For example, we estimated that the most plausible paraphrase for the compound porcelain doll was 'a doll made of porcelain', so it was categorized under the noun MADE OF modifier relation. Further, compounds were distributed into two lists in which they were divided into targets and primes, each belonging to different categories ( $\mathrm{pRpL}, \mathrm{pRmL}, \mathrm{mRpL}, \mathrm{mRmL}$ ). The ' $\mathrm{pR} / \mathrm{mR}$ ' refers to congruence (' $\mathrm{p}$ ' for plus/congruent) or incongruence (' $\mathrm{m}$ ' for minus/incongruent) of the underlying head-modifier relationship between prime and target, while ' $\mathrm{pL} / \mathrm{mL}$ ' denotes whether prime and target compounds share (' $\mathrm{p}$ ' for plus/sharing) or do not share (' $\mathrm{m}$ ' for minus/not sharing) a constituent lexeme. In the end, each category ( $\mathrm{pRpL}, \mathrm{pRmL}, \mathrm{mRpL}, \mathrm{mRmL}$ ) had three conditions for the three different modifier-head relations - [noun MADE OF modifier], [noun IN modifier], [noun FOR modifier], and each condition had three noun-noun compounds as targets. The total sum was nine noun-noun compounds per category, which gave 36 compounds per list. 
To counter-balance the potential effects of individual compounds in the conditions including only lexical priming and only relation priming $(\mathrm{mRpL}$ and $\mathrm{pRmL}$, respectively), we created two lists of stimuli. Compounds placed in the $\mathrm{mRpL}$ condition in List 1 were put in the $\mathrm{pRmL}$ condition in List 2 and vice versa (cf. Table 3 and Table 4). The participants were randomly assigned to either List 1 or List 2 so that each participant saw only one of the two lists and each list had an equal, or close to equal, number of participants assigned to it.

It was important that the single elements of a compound (modifiers and heads) do not occur more than was needed so that the reoccurring of words would not influence the reaction time. Thus, all nouns were used only once as heads or modifiers in primes and targets, except, of course, in cases of ' $\mathrm{pL}$ ' compounds, where repetition was allowed. All target items were balanced for the number of syllables, so that every head had one syllable and every modifier two syllables. Since we assumed that the length of primes should not have an effect on RT, their length did not need to fulfil this requirement. Primes and targets needed to be matched in number. For example, if a prime was used in its plural form, the target also had to be in plural. Additionally, the frequency of compounds was taken into consideration for both primes and targets. The initial idea was to use compounds that do not have fewer than 40 tokens in COCA ( 0.077 per million words).

Table 3. Examples of experimental stimuli for all conditions (List 1)

\begin{tabular}{lllllllll}
\hline & \multicolumn{2}{c}{$\mathrm{pRpL}$} & \multicolumn{2}{c}{$\mathrm{mRpL}$} & \multicolumn{2}{c}{$\mathrm{pRmL}$} & \multicolumn{2}{c}{$\mathrm{mRmL}$} \\
& Prime & Target & Prime & Target & Prime & Target & Prime & Target \\
\hline $\mathrm{N}$ made & paper & paper & pumpkin & pumpkin & porcelain & iron & hunting & wire \\
of M & cup & plate & seeds & pies & doll & stove & license & fence \\
\hline & downtown & downtown & prison & prison & garden & hotel & body & river \\
$\mathrm{N}$ in M & restaurant & street & break & yard & plant & bed & parts & stones \\
\hline & water & water & cigar & cigar & dish & butter & oil & sugar \\
$\mathrm{N}$ for M & pipe & tank & smoke & box & towel & knife & paint & bowl \\
\hline
\end{tabular}

Table 4. Examples of experimental stimuli for all conditions (List 2)

\begin{tabular}{|c|c|c|c|c|c|c|c|c|}
\hline & \multicolumn{2}{|c|}{$\mathrm{pRpL}$} & \multicolumn{2}{|c|}{$\mathrm{mRpL}$} & \multicolumn{2}{|c|}{$\mathrm{pRmL}$} & \multicolumn{2}{|c|}{$\mathrm{mRmL}$} \\
\hline & Prime & Target & Prime & Target & Prime & Target & Prime & Target \\
\hline $\begin{array}{l}\mathrm{N} \text { made } \\
\text { of } \mathrm{M}\end{array}$ & $\begin{array}{l}\text { paper } \\
\text { cup }\end{array}$ & $\begin{array}{l}\text { paper } \\
\text { plate }\end{array}$ & $\begin{array}{l}\text { iron } \\
\text { deficiency }\end{array}$ & $\begin{array}{l}\text { iron } \\
\text { stove }\end{array}$ & $\begin{array}{l}\text { porcelain } \\
\text { doll }\end{array}$ & $\begin{array}{l}\text { pumpkin } \\
\text { pies }\end{array}$ & $\begin{array}{l}\text { hunting } \\
\text { license }\end{array}$ & $\begin{array}{l}\text { wire } \\
\text { fence }\end{array}$ \\
\hline $\mathrm{N}$ in $\mathrm{M}$ & $\begin{array}{l}\text { downtown } \\
\text { restaurant }\end{array}$ & $\begin{array}{l}\text { downtown } \\
\text { street }\end{array}$ & $\begin{array}{l}\text { hotel } \\
\text { reservation }\end{array}$ & $\begin{array}{l}\text { hotel } \\
\text { bed }\end{array}$ & $\begin{array}{l}\text { garden } \\
\text { plant }\end{array}$ & $\begin{array}{l}\text { prison } \\
\text { yard }\end{array}$ & $\begin{array}{l}\text { body } \\
\text { parts }\end{array}$ & $\begin{array}{l}\text { river } \\
\text { stones }\end{array}$ \\
\hline $\mathrm{N}$ for $\mathrm{M}$ & $\begin{array}{l}\text { water } \\
\text { pipe }\end{array}$ & $\begin{array}{c}\text { water } \\
\text { tank }\end{array}$ & $\begin{array}{c}\text { butter } \\
\text { cake }\end{array}$ & $\begin{array}{l}\text { butter } \\
\text { knife }\end{array}$ & $\begin{array}{l}\text { dish } \\
\text { towel }\end{array}$ & $\begin{array}{l}\text { cooking } \\
\text { spray }\end{array}$ & $\begin{array}{l}\text { oil } \\
\text { paint }\end{array}$ & $\begin{array}{l}\text { sugar } \\
\text { bowl }\end{array}$ \\
\hline
\end{tabular}


Frane Malenica - Lucija Žinić:

Garden plants and butter knives - the effects of lexical and relation priming on nominal compound processing by native and non-native speakers of English

However, due to the initial low number of possible candidates for the material, the frequency limit was lowered in some cases. Subsequent data analysis (in Section 4) showed no statistically significant effect of frequency on RT.

In order to mask the goal of this research, two groups of fillers were created. The first group included phonologically possible but unattested words which were created by replacing or removing one or more letters from actual English words (e.g. ingus far, slinker meen, pist ilkier). The second group was created using existing the words but in non-grammatical combinations (e.g. truck yellow, coffee learn, smell bruise). This yielded 44 fillers overall. In the experiment, the fillers were organized so that phonologically possible but unattested words acted as primes which were followed by existing words but in ungrammatical combinations as targets and vice versa.

After the lists were finalized, all the primes and targets were presented to a separate group of 15 non-native students of English to see which compounds could be used in the experiment. They were instructed to write the meaning and/or description of these words, in as much detail as they could. The students took 10 to 15 minutes to fill in the questionnaire. None of the compounds remained unexplained in more than 3 cases, which we took as an indication that the potential participants are familiar with the compounds used in the experiment. None of the participants from the pre-test/material testing took part in the final experiment and vice versa.

\subsection{Experiment}

The compounds were inserted into the IBEX Farm platform for experiments (Drummond 2011). Each list had a separate version for left-handed participants and for right-handed participants. All non-native participants were second year BA students of English ( $\mathrm{N}=40, \mathrm{M}=15 \%, \mathrm{~F}=85 \%)$ and all of them were native speakers of Croatian. ${ }^{14}$ According to the program of the Department of English of University of

\footnotetext{
${ }^{14}$ An anonymous reviewer has pointed out that it would be beneficial to explore the similarities and differences between compounds in English and the native language of non-native speakers (Croatian). While we agree with this opinion, a detailed discussion is beyond the scope of this paper. Generally, typical Croatian compounds have a different morphological structure than English NounNoun (NN) compounds used in our research - they rarely involve more than two bases (English NN compounds are recursive); the bases are connected with an interfix, typically $-o-$, but also $-u$ - and $-e-$ ; and the right-hand element often contains a suffix, e.g. minobacač 'mine-o-thrower' (Babić 2002). They are spelled as single words, which represents another significant difference between them and $\mathrm{NN}$ compounds used in our research. However, Croatian endocentric compounds are right-headed
} 


\section{EZIKOSLOVLJE \\ 20.3 (2019): 497-530}

Zadar, all participants had acquired the $\mathrm{C} 1$ level according to the Common European Framework of Reference for Languages. Between five and 12 participants were assigned to each of the five experiment sessions. The experiment was conducted in a classroom equipped with personal computers at the University of Zadar and two researchers were present at each session. The room was quiet, without any visual or audible distractions. All non-native participants received course credit for their participation in the experiment and provided informed written consent. The participants took approximately 15 minutes to finish the experiment consisting of 80 experimental and five practice tasks. The data from the native participants were collected in individual sessions under comparable conditions, conducted among students at the University College London and the University of Graz ( $\mathrm{N}=14$, $\mathrm{M}=35.7 \%, \mathrm{~F}=64.3 \%) .{ }^{15}$

The participants were instructed to use the index fingers on both their hands and press one of the keys to indicate whether the second sequence of letters makes a meaningful unit in the English language. The experiment was designed so that the participants used their dominant hand for YES and the non-dominant hand for NO (as in Gagné \& Shoben 1997). Hence, the right-handed participants used the "K" key for YES and the "F" key for NO, while the left-handed participants used the "K" key for NO, and the "F" key for YES. Since the targets used in our experiments were all existing words in English and thus meaningful units, the response bias for YES answers was counterbalanced with fillers (see Section 3.1 and the Appendix), which were all ungrammatical and thus not meaningful combinations of words in English.

During their practice session, the participants had five practice items to familiarize themselves with the task and the interface of the experiment. At the beginning of every task they would see a fixation cross $(2,000 \mathrm{~ms})$, followed by the first (prime) two-word sequence $(2000 \mathrm{~ms})$, and then the second (target) sequence with the YES/NO buttons underneath. The YES/NO buttons would remain on the screen until the participant pressed a key. Tasks were separated by a 3,000 ms blank screen.

just like the compounds in English, which was probably a facilitating factor in our experiment (cf. De Cat et al. 2014; 2015).

15 The authors would like to thank Jakov Proroković and Jana Willer Gold for their help in recruiting the native participants. 
Frane Malenica - Lucija Žinić:

Garden plants and butter knives - the effects of lexical and relation priming on nominal compound processing by native and non-native speakers of English

\section{Results and discussion}

The data obtained by the method described in Section 3.2 were loaded into the $\mathrm{R}$ statistical software package (R Core Team 2015). Non-native participant provided 36 observations ( $4 \times 9$ for every prime-target combination), which gave a grand total of 1,440 observations. In terms of accuracy, the correct answer (YES) was provided for 1,273 items altogether (88.4\%), but some of these observations had to be excluded from further analysis. Namely, one participant did not use both index fingers during the experiment, so their results were excluded from further analysis. In addition, the data from participants who failed to obtain over $60 \%$ accuracy rate for critical conditions $(\mathrm{N}=3)$ were also excluded from further analysis. Eliminating these participants allowed us to analyse the correlation between accuracy and prime-target and modifier-head relations more precisely.

The RT results were then further filtered by removing the outliers, i.e. all observations over 2 standard deviations away from the mean (cf. Table 5). This resulted in removal of 291 observations (20.2\%) and gave us the final total of 1,149 data points. The observations for each participant were aggregated across prime-target and modifier-head relations so that each participant provided 12 data points at most and this aggregated set of data was the basis for our further analysis.

The data for the native participants were filtered and aggregated using the same method as described above. Each native participant provided a total of 36 observations, thus yielding a total of 504 data points. As no anomalous behaviour was noted in their responses, no participants were disqualified from further analysis. Their overall accuracy was higher than for non-native participants, as they provided the correct answer in 474 instances $(94.05 \%)$.

Table 5. Reaction time across prime-target relations for non-native participants (before the removal of outliers)

\begin{tabular}{lllll}
\hline & mRmL & mRpL & pRmL & pRpL \\
\hline mean & 1157.35 & 988.549 & 1070.42 & 962.992 \\
\hline SD & 295.145 & 237.04 & 310.47 & 240.82 \\
\hline
\end{tabular}

Table 6. Reaction time across modifier-head relations (within targets) for non-native participants (before the removal of outliers)

\begin{tabular}{llll}
\hline & N for $\mathbf{M}$ & $\mathbf{N}$ in $\mathbf{M}$ & N made of $\mathbf{M}$ \\
\hline mean & 1035.64 & 1046.73 & 1052.26 \\
\hline SD & 282.88 & 285.47 & 280.87 \\
\hline
\end{tabular}


Table 7. Reaction time across prime-target relations for native participants (before the removal of outliers)

\begin{tabular}{lllll}
\hline & mRmL & mRpL & pRmL & pRpL \\
\hline mean & 959.28 & 872.23 & 894.82 & 789.83 \\
\hline SD & 585.26 & 467.67 & 426.14 & 311.79 \\
\hline
\end{tabular}

Table 8. Reaction time across modifier-head relations (within targets) for native participants (before the removal of outliers)

\begin{tabular}{llll}
\hline & $\mathbf{N}$ for $\mathbf{M}$ & $\mathbf{N}$ in $\mathbf{M}$ & $\mathbf{N}$ made of $\mathbf{M}$ \\
\hline mean & 868.82 & 884.92 & 878.64 \\
\hline SD & 410.70 & 536.06 & 421.64 \\
\hline
\end{tabular}

The data for both groups of participants were distributed normally, which is why parametric tests were used in further analysis. A linear mixed effects model was created to analyse the interaction of different factors. ${ }^{16}$ The model was created using the lme4 package in R (Bates et al. 2012). Prime-target relations, modifier-head relations, and native language of participants were set as fixed effects, while participants and items were entered into the model as random effects.

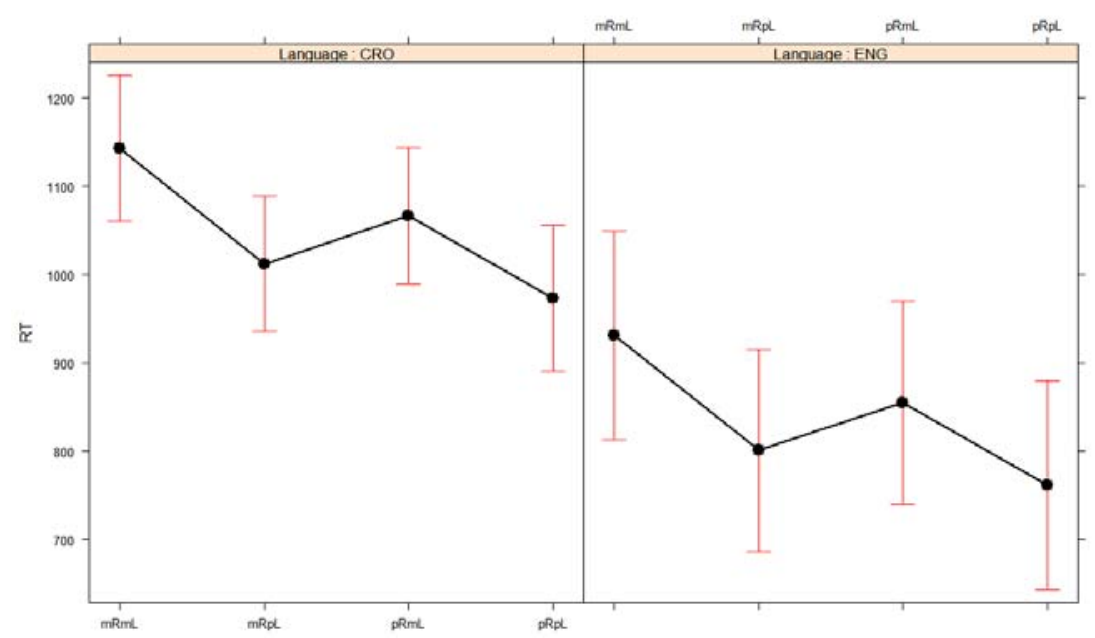

Figure 1. The effect of prime-target relations on RT across both groups of participants

\footnotetext{
${ }^{16}$ We would like to thank the anonymous reviewer for suggesting the use of mixed effects modelling.
} 
Frane Malenica - Lucija Žinić:

Garden plants and butter knives - the effects of lexical and relation priming on nominal compound processing by native and non-native speakers of English

No deviations from homoscedasticity or normality were observed through visual inspection of residual plots. The model has shown a highly significant effect of prime-target relation $(\chi 2(3)=26.496, p<0.001)$ (Figure 1), a significant effect of native language $(\chi 2(1)=9.5915, \mathrm{p}<0.01)$ (Figure 2$)$, and no significant effect of modifier-head relation $(\chi 2(2)=0.139, \mathrm{p}<0.9328)$. The difference in accuracy rates between native and non-native participants was highly significant $\left(\chi^{2}=12.45, \mathrm{df}=1\right.$, $\mathrm{p}<0.001)$. While the difference between the two groups in terms of RT and accuracy rate was fairly unsurprising, an interesting pattern can be observed in Table 5, Table 7, and Figure 1. Even though the two groups differ significantly in terms of reaction times across all four prime-target combinations, they pattern identically in terms of priming effects. The fastest reaction times for both groups were obtained in the $\mathrm{pRpL}$ condition and the slowest RTs were obtained in the $\mathrm{mRmL}$ condition, while the $\mathrm{mRpL}$ condition yielded faster reaction times than the $\mathrm{pRmL}$ condition. Specifically, the combination of relation and lexical priming yielded the strongest facilitation effects while the neutral condition yielded the slowest RT. A stronger facilitation effect was noted in the condition with only lexical priming than in the condition with only relation priming. To investigate further differences within both groups of participants, their data are analysed separately in the following subsections.

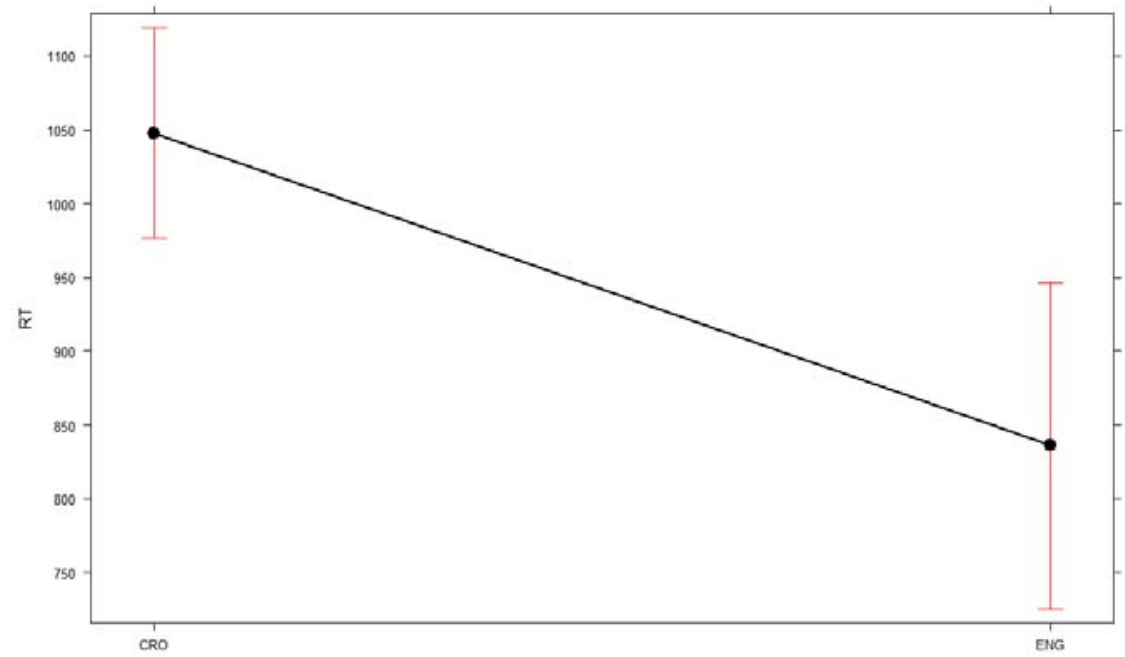

Figure 2. The effect of native language of participants on RT 


\subsection{Results for the non-native participants}

If we look at the data in Tables 5 and 6 and Figure 1, we can notice several general trends:

1) as expected, the conditions $\mathrm{mRmL}$ (-relation, -lexical) and $\mathrm{pRpL}$ (+relation, +lexical) represent the most extreme values as they are groups with no priming and both types of priming involved;

2) there seems to be no major difference between the groups $\mathrm{mRpL}$ and $\mathrm{pRpL}$;

3) with both $\mathrm{mL}$ (-lexical) and $\mathrm{pL}$ (+lexical) pairs (pRmL-mRmL and $\mathrm{pRpL}-$ $\mathrm{mRpL}$ ), the RT of the condition with relation priming is lower;

4) there seems to be no significant difference between the types of modifierhead relations.

A chi-squared test showed no significant effects of either prime-target relations $\left(\chi^{2}=5.3428, \mathrm{df}=3, \mathrm{p}=0.148\right)$ or the modifier-head relations $\left(\chi^{2}=2.0091, \mathrm{df}=2\right.$, $\mathrm{p}=0.3662)$ on accuracy. We conducted a one-way ANOVA with the type of modifier-head relation as the predictor variable and the RT as the response variable. The results show a statistically significant effect of prime-target relations on reaction time, $F(3,422)=11.01, \mathrm{p}<0.001$. The post hoc TukeyHSD test shows that the difference is highly significant between the two baseline conditions $\mathrm{pRpL}$ and $\mathrm{mRmL}$ $(\mathrm{p}<0.001)$, and the two conditions differing in terms of lexical priming $-\mathrm{mRpL}$ and $\mathrm{mRmL}(\mathrm{p}<0.001)$. Thus, when we compare the two conditions which differ only in terms of relation priming, there is no significant difference between the two, which would indicate that the non-native participants are not sensitive to relation priming alone. Another one-way ANOVA was conducted to analyse the effects of different individual modifier-head relations on $\mathrm{RT}$, but it did not prove to be statistically significant, $\mathrm{F}(2,423)=0.127, \mathrm{p}=0.88$.

The final test was conducted to establish a possible correlation between the frequency of prime and target compounds and reaction time. The data were aggregated for every item so that the normalized frequency would remain constant and the RT value would represent the mean across all participants, which gave a total of 36 observations ( 1 for each item). Simple linear regression analysis has shown no statistically significant influence of normalized frequency of prime compounds $\left(\mathrm{R}^{2}=0.0004531, \mathrm{~F}(1,34)=0.01541, \mathrm{p}=0.9019\right)$ and a statistically significant effect of normalized frequency of target compounds on reaction time $\left(\mathrm{R}^{2}=0.1543\right.$, $\mathrm{F}(1,34)=6.202, \mathrm{p}<0.05)$. 
Frane Malenica - Lucija Žinić:

Garden plants and butter knives - the effects of lexical and relation priming on nominal compound processing by native and non-native speakers of English

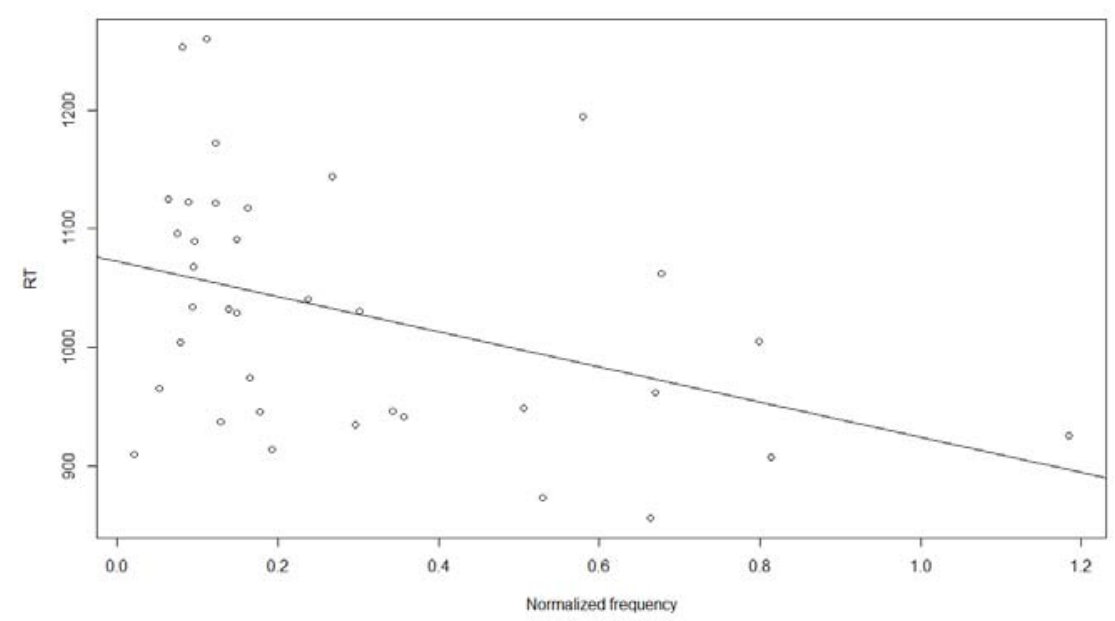

Figure 3. Interaction of reaction time and normalized frequency for target compounds

\subsection{Results for the native participants}

By looking at the data in Tables 7 and 8 , similar observations can be made as for the data gathered from the non-native participants. The most extreme values are found for conditions without any priming at all $(\mathrm{mRmL})$ and with both types of priming $(\mathrm{pRpL})$. Also, both pairs which differ only in terms of relation priming (mRmL-pRmL and $\mathrm{mRpL}-\mathrm{pRpL}$ ) have faster reaction times in the condition with relation priming, and there seems to be very little difference in modifier-head relations.

A chi-squared test showed a statistically significant correlation between primetarget relations and accuracy $(\chi 2=10.349, \mathrm{df}=3, \mathrm{p}<0.05)$, but not modifier-head relations and accuracy $(\chi 2=0.21266, \mathrm{df}=2, \mathrm{p}=0.8991)$. This would seem to indicate that native speakers are sensitive to the type of prime-target relations, as one would expect from previous research (Gagné \& Spalding 2004) and Figure 1, but not to the type of relationship between the compound constituents.

The data for every participant were aggregated across the four prime-target and three modifier-head relations, which yielded a total of 167 observations (12 observations per participant at most). The values for modifier-head relations showed very little difference at first glance, and a one-way ANOVA confirmed that it had no statistically significant effect, $F(2,39)=0.023$, $p=0.977$. Another one-way ANOVA was conducted using the prime-target relation as a factor and it also showed no statistically significant effects of prime-target relations on $\mathrm{RT}, \mathrm{F}(3,52)=0.805$, $\mathrm{p}=0.119$. There are good indications to believe that this was caused by the small 
sample size $(\mathrm{N}=14)$ as a one-way ANOVA conducted on non-aggregated values, i.e. individual observations for every participant, does reach statistical significance $(\mathrm{F}(3,470)=3.014, \mathrm{p}<0.05)$ with similar effects as for the non-native participants, which was not the case for ANOVA with modifier-head relations as the predictor variable.

The linear regression models conducted to compare the correlation between frequency and reaction times provide somewhat different results than for non-native participants. No statistically significant correlation was found between the normalized frequency of prime $\left(\mathrm{R}^{2}=0.00532, \mathrm{~F}(1,34)=0.1819, \mathrm{p}=0.6725\right)$ or target compounds $\left(\mathrm{R}^{2}=0.03609, \mathrm{~F}(1,34)=1.273, \mathrm{p}=0.2671\right)$, which rules out the effects of frequency among the native English speakers in our study. However, the lack of frequency effects might have been caused by low number of native speaker participants in our study.

\subsection{Discussion}

The study presented here set out to partially replicate the results of Gagné \& Spalding (2004) and test whether the effects they reported could be extended to highly proficient non-native speakers of English. Although different settings in which the experiments took place (parallel sessions vs. individual sessions) and the difference in group size prevent us from considering the differences in results as conclusive, it is still interesting to note that reaction times for non-native participants were around 100-200 ms slower for all four types of primes, which is in line with our expectations.

As was mentioned in Section 2, the study in Gagne \& Spalding (2004) had three prime-target conditions in which a compound (e.g. earring) was preceded by a neutral prime (toothpaste), a different relation prime (earhole), or the same relation prime (eardrops), and these conditions are equivalent to the three conditions in our study ( $\mathrm{mRmL}, \mathrm{mRpL}$, and $\mathrm{pRpL})$. Interestingly enough, the difference in reaction times between the fastest and the slowest condition (same relation vs. neutral condition) in Experiment 1 in Gagné \& Spalding (2004: 482) is $153 \mathrm{~ms}$, while the difference between equivalent conditions in our study is $175 \mathrm{~ms}$ for non-native participants, and $147 \mathrm{~ms}$ for native participants. This might indicate that the statistical significance achieved by Gagné \& Spalding (2004) and the lack thereof between particular groups in our study (cf. Section 4.1 and Section 4.2) might be due to a bigger sample of participants and/or larger number of items in Gagné \& Spalding (2004). 
Frane Malenica - Lucija Žinić:

Garden plants and butter knives - the effects of lexical and relation priming on nominal compound processing by native and non-native speakers of English

Generally speaking, the data collected from the native participants do not speak directly in favour of the proposal in Gagné \& Spalding (2004), in the sense that they do not confirm it with statistical significance, but the trend and the pattern our data show are certainly in line with it and provide some interesting insights. The effect of prime-target relations was shown to be statistically significant, but since the post hoc tests failed to confirm a statistically significant difference between the conditions differing only in terms of relation priming, we cannot claim that relation priming alone has a significant effect on non-native speakers, which is in line with what Lee (2011) reports.

At best, the data seem to suggest that it works in conjunction with other factors - lexical priming (repetition priming in Gagné \& Spalding 2004) and frequency. The effect of lexical priming is supported by the post hoc test as it showed a statistically significant difference between pairs of conditions differing in terms of lexical priming. Given that root compounds in Croatian and other Slavic languages (e.g. Polish) are not as productive as English compounds (Szymanek 2009, Grčević 2015), reliance on lexical factors is actually understandable. Another potential piece of evidence for the primacy of lexical priming over relation priming is the difference between the two conditions, viz. with lexical priming (pRpL-mRpL) and without it (pRmL-mRmL). The difference between the first pair was only 25.56 milliseconds, while the difference between the latter pair was 86.93 milliseconds. This could be taken as an indication that relation priming plays a less prominent role when there are other factors involved, such as lexical priming.

The frequency effects of target items were corroborated by the linear regression model, which showed that participants provided faster responses with more frequent items. This finding is in line with those of Clahsen \& Neubauer (2010) for complex words in German. The frequency of the item which preceded the tested compound (i.e. frequency of primes) had no bearing on reaction time.

Despite the fact that prime-target relations did not have a statistically significant effect on reaction times for native speakers, the native participant data did, however, provide several insights which support the claims from Gagné \& Spalding (2004). A statistically significant effect of prime-target on accuracy was noted, and the comparison of conditions differing in terms of relation priming ( $\mathrm{mRpL}-\mathrm{pRpL}$, $\mathrm{mRmL}-\mathrm{pRmL}$ ) in Table 7 shows that the average reaction time values were lower for conditions with relation priming by approximately 82 and 62 milliseconds, respectively. According to the CARIN (Competition-Among-Relations-In-Nominals) theory, proposed in Gagné \& Shoben (1997), Gagné \& Spalding (2004), among others, the processing of compounds involves activation of all potential relations 
which compete for activation and recent activation of a particular relation facilitates its chances for selection. The tendencies in our native participant data seem to speak in favour of this view.

Compound processing among the non-native English speakers seems to operate on similar principles, but with more emphasis on frequency and lexical priming as the stronger factors in the equation. Our explanation for this rests on the assumption that native speakers are more familiar with all target compounds used in the experiment and are, thus, more likely to have them all stored in the mental lexicon with information about possible modifier-head relations. Non-native participants are less likely to have all compounds stored with their relations, which is why other strategies might be relied upon in their processing. The effects of frequency on target items are particularly illustrative in this respect - the higher the frequency of a compound, the higher the chance it was at least partially stored in the mental lexicon, and the faster its retrieval. If this is truly the case, one might ask why the nonnative participants are not more sensitive to relation priming. An answer which we find highly plausible is that prime compounds probably suffered from the same "defective" storage as target compounds. Given that both prime and target compounds used in the experiments were of comparable frequency, the potential problem of identifying the modifier-head relation in target compounds would apply to primes as well.

Another noteworthy finding of this study is that the type of modifier-head relation does not have a significant effect on reaction times or accuracy in both groups of participants. These results are in line with the claims in Shoben (1991) and Gagné \& Shoben (1997) that there seems to be no difference in degree of complexity between types of relations. What this suggests is that while speakers may be sensitive to modifier-head relations in compounds, as proposed by Levi (1978) and Jackendoff $(2009 ; 2010)$, they do not seem to be more sensitive to some relations than others. Going back to the CARIN theory, these results are readily explained by its competition-among-relations model as they offer no evidence of preference for one relation over the other. Obviously, one would have to include more different relations in a study like this in order to make this latter claim more conclusive.

Lastly, it is worth noting that even though the study confirmed that native and non-native speakers do not have the same reaction time, their responses to the two types of primes pattern almost identically. While it is not possible to make any hard claims based on the data of this study (for reasons outlined above), it seems plausible that an additional study with more data points (more participants and/or more items) would be able to yield a statistically significant result. 
Frane Malenica - Lucija Žinić:

Garden plants and butter knives - the effects of lexical and relation priming on nominal compound processing by native and non-native speakers of English

Another avenue of research covered by Gagné \& Shoben (1997), which we do not pursue here for reasons of space, is the effect of frequency of occurrence of individual modifiers and heads within particular relations, operationalized in the form of entropy by Schmidtke et al. (2016). Interestingly enough, Gagné \& Shoben report frequency effects for modifiers but not heads in English noun-noun compounds and cite evidence of similar effects in other languages. We believe this would be a hypothesis worth investigating with both groups of participants (native and non-native) used in this study.

\section{Conclusion}

The aim of this study was to see how and to what extent relation priming and lexical priming affect the speed of recognition of noun-noun compounds with native and non-native speakers. While the non-native participant data did provide confirmation that different types of priming have an effect on reaction time, they did not provide a basis from which the effects of relation or lexical priming could be conclusively isolated. The data also showed an effect of normalized frequency on reaction time among the non-native participants, which was not noted among the native participants. The native participant data, on the other hand, provided only indications of both relation and lexical priming - accuracy rates showed the effects of different types of priming, while reaction time data only provided trends which failed to reach statistical significance, possibly due to a low number of participants. Another question proposed was whether modifier-head relations have any influence on reaction time and the conclusion is the same for both groups of participants, namely that the modifier-head relations do not have any significant influence on the speed of recognition. While our research did not completely replicate the results of Gagné \& Spalding (2004), it did not conclusively rule out their proposal for native participants either. The data presented in this paper have shown that native speakers process nominal compounds faster than non-native speakers, but that the two groups have nearly identical patterns of reaction to different combinations of relation and lexical priming. However, the data presented here shows that compound processing among non-native speakers operates on somewhat different principles than for native speakers, with frequency and priming effects (lexical or relation) both playing a prominent role. 


\section{EZIKOSLOVLJE \\ 20.3 (2019): 497-530}

\section{References}

Babić, Stjepan. 2002. Tvorba riječi u hrvatskome književnome jeziku. Zagreb: Nakladni zavod Globus.

Bates, Douglas \& Mächler, Martin \& Bolker, Ben \& Walker, Steve. 2015. Fitting linear mixed-effects models using lme4. Journal of Statistical Software 67(1). 1-48. doi: 10.18637/jss.v067.i01

Bickerton, Derek. 1990. Language \& species. Chicago: University of Chicago Press.

Booij, Geert. 2009. Compounding and construction morphology. In Lieber, Rochelle \& Štekauer, Pavol (eds.), The Oxford handbook of compounding, 201-216. Oxford: Oxford University Press. doi: 10.1093/oxfordhb/9780199695720.001.0001

Booij, Geert. 2010. Construction morphology. 3rd edn. Oxford: Oxford University Press.

Cieślicka, Anna. 2006. Literal salience in on-line processing of idiomatic expressions by second language learners. Second Language Research 22(2). 115-144. doi: 10.1191/0267658306sr263oa

Clahsen, Harald \& Neubauer, Kathleen. 2010. Morphology, frequency, and the processing of derived words in native and non-native speakers. Lingua 120(11). 2627-2637. doi: 10.1016/j.lingua.2010.06.007

Conklin, Kathy \& Schmitt, Norbert. 2008. Formulaic sequences: are they processed more quickly than nonformulaic language by native and nonnative speakers? Applied Linguistics 29(1). 72-89. doi: 10.1093/applin/amm022

Coolen, Riet \& Van Jaarsveld, Henk J. \& Schreuder, Robert. 1991. The interpretation of isolated novel nominal compounds. Memory \& Cognition 19(4). 341-352. doi: 10.3758/BF03197138

Davies, Mark. 2008. The Corpus of Contemporary American English (COCA): 560 million words. Available online at https://corpus.byu.edu/coca/

DeCat, Cecile \& Klepousniotou, Ekaterini \& Baayen, Harald. 2014. Electrophysiological correlates of noun-noun compound processing by non-native speakers of English. Proceedings of the First Workshop on Computational Approaches to Compound Analysis (ComAComA 2014), 41-52. doi: 10.3115/v1/W14-5705

De Cat, Cecile \& Klepousniotou, Ekaterini \& Baayen, R. Harald. 2015. Representational deficit or processing effect? An electrophysiological study of noun-noun compound processing by very advanced L 2 speakers of English. Frontiers in Psychology 6 (article 77). 1-17. doi: 10.3389/fpsyg.2015.00077

Diependaele, Kevin \& Duñabeitia, Jon Andoni \& Morris, Joanna, \& Keuleers, Emmanuel. 2011. Fast morphological effects in first and second language word recognition. Journal of Memory and Language 64(4). 344-358. https://doi.org/10.1016/j.jml.2011.01.003

Downing, Pamela. 1977. On the creation and use of English compound nouns. Language 53(4). 810-842. doi: 10.2307/412913 
Frane Malenica - Lucija Žinić:

Garden plants and butter knives - the effects of lexical and relation priming on nominal compound processing by native and non-native speakers of English

Drummond, Alex. 2011. IbexFarm. Version 0.3.9. Available at http://spellout.net/ibexfarm/.

Feldman, Laurie Beth \& Kostić, Aleksandar \& Basnight-Brown, Dana M. \& FilipovićĐurđević, Dušica \& Pastizzo, Matthew John. 2010. Morphological facilitation for regular and irregular verb formations in native and non-native speakers: Little evidence for two distinct mechanisms. Bilingualism: Language and Cognition 13(2). 119-135. doi: 10.1017/S1366728909990459

Fiorentino, Robert, \& Poeppel, David. 2007. Compound words and structure in the lexicon. Language and Cognitive Processes 22(7). 953-1000. doi: 10.1080/01690960701190215

Gagné, Christina L. 2002. Lexical and relational influences on the processing of novel compounds. Brain and Language 81(1-3). 723-735. doi: 10.1006/brln.2001.2559

Gagné, Christina L. 2009. Psycholinguistic perspectives. In Lieber, Rochelle \& Štekauer, Pavol (eds.), The Oxford handbook of compounding, 255-271. Oxford: Oxford University Press. doi: 10.1093/oxfordhb/9780199695720.001.0001

Gagné, Christina L. \& Shoben, Edward J. 1997. Influence of thematic relations on the comprehension of modifier-noun combinations. Journal of Experimental Psychology: Learning, Memory, and Cognition 23(1). 71-87. https://doi.org/10.1037/02787393.23.1.71

Gagné, Christina L. \& Spalding, Thomas L. 2004. Effect of relation availability on the interpretation and access of familiar noun-noun compounds. Brain and Language 90(13). 478-486. doi: 10.1016/S0093-934X(03)00459-0

Gagné, Christina L. \& Spalding, Thomas L. 2010. Relational competition during compound interpretation. In Scalise, Sergio \& Vogel, Irene (eds.), Cross-disciplinary issues in compounding, 287-300. Amsterdam: John Benjamins. https://doi.org/10.1075/cilt.311

Gagné, Christina L. \& Spalding, Thomas L. \& Gorrie, Melissa C. 2005. Sentential context and the interpretation of familiar open-compounds and novel modifier-noun phrases. Language and Speech 48(2). 203-219. https://doi.org/10.1177/00238309050480020401

González Alonso, Jorge \& Baquero Castellanos, Silvia \& Müller, Oliver. 2016. Masked constituent priming of English compounds in native and non-native speakers. Language, Cognition and Neuroscience 31(8). 1038-1054. doi: 10.1080/23273798.2016.1179770

Grčević, Mario. 2015. Croatian. In Müller, Peter O. \& Ohnheiser, Ingeborg \& Olsen, Susan \& Rainer, Franz (eds.), Word-Formation: An international handbook of the languages of Europe, 2998-3016. Berlin: Mouton de Gruyter.

Jackendoff, Ray. 2009. Compounding in the parallel architecture and conceptual semantics. In Lieber, Rochelle \& Štekauer, Pavol (eds.), The Oxford handbook of compounding, 105-128. Oxford: Oxford University Press. doi: 10.1093/oxfordhb/9780199695720.001.0001 
Jackendoff, Ray. 2010. Meaning and the lexicon: The Parallel Architecture 1975-2010. New York: Oxford University Press.

Jackendoff, Ray \& Wittenberg, Ewa. 2014. What you can say without syntax: a hierarchy of grammatical complexity. In Newmeyer, Frederick J. \& Preston, Laurel B. (eds.), Measuring grammatical complexity ( $1^{\text {st }}$ edn.), 65-82. Oxford: Oxford University Press.

Ji, Hongbo \& Gagné, Christina L. \& Spalding, Thomas L. 2011. Benefits and costs of lexical decomposition and semantic integration during the processing of transparent and opaque English compounds. Journal of Memory and Language 65(4). 406-430. doi: 10.1016/j.jml.2011.07.003

Kay, Paul \& Zimmer, Karl. 1990. On the semantics of compounds and genitives in English. In Tsohatzidis, Savas (ed.), Meanings and prototypes: Studies in linguistic categorization, 239-246. London: Routledge.

Langacker, Ronald. 1987. Foundations of Cognitive Grammar: Volume I: Theoretical prerequisites. Stanford: Stanford University Press.

Lee, Junkyu. 2011. The activations of relational structures in processing second language noun-noun compound. Linguistic Research 28(1). 143-157.

Lees, Robert B. 1960. The Grammar of English nominalizations. $5^{\text {th }}$ printing. The Hague: Mouton.

Levi, Judith N. 1978. The syntax and semantics of complex nominals. New York: Academic Press.

Libben, Gary \& Derwing, Bruce L. \& de Almeida, Roberto G. 1999. Ambiguous novel compounds and models of morphological parsing. Brain and Language 68(1-2). 378386. https://doi.org/10.1006/brln.1999.2093

Lieber, Rochelle. 1983. Argument linking and compounds in English. Linguistic Inquiry 14(2). 251-285.

Marslen-Wilson, William D. \& Tyler, Lorraine K. 2007. Morphology, language and the brain: the decompositional substrate for language comprehension. Philosophical Transactions of the Royal Society B: Biological Sciences 362(1481). 823-836. https://doi.org/10.1098/rstb.2007.2091

Murphy, Gregory L. 1990. Noun phrase interpretation and conceptual combination. Journal of Memory and Language 29(3). 259-288. https://doi.org/10.1016/0749596X(90)90001-G

Olsen, Susan. 2000. Composition. In Booij, Geert \& Lehmann, Christina \& Mugdan, Joachim \& Skopeteas, Stavros \& Kesselheim, Wolfgang (eds.), Morphologie: ein internationales Handbuch zur Flexion und Wortbildung = Morphology: an international handbook on inflection and word-formation, 897-916. Berlin: De Gruyter.

Pashler, Harold \& Wagenmakers, Eric-Jan. 2012. Editors' introduction to the special section on replicability in psychological science: a crisis of confidence? Perspectives on Psychological Science 7(6). 528-530. https://doi.org/10.1177/1745691612465253 
Frane Malenica - Lucija Žinić:

Garden plants and butter knives - the effects of lexical and relation priming on nominal compound processing by native and non-native speakers of English

Plag, Ingo \& Kunter, Gero \& Lappe, Sabine \& Braun, Maria. 2008. The role of semantics, argument structure, and lexicalization in compound stress assignment in English. Language 84(4). 760-794. doi: 10.1353/lan.0.0072

R Core Team 2015. R: A language and environment for statistical computing. R Foundation for Statistical Computing, Vienna, Austria. URL: https://www.R-project.org/.

Roeper, Thomas \& Siegel, Muffy E.A. 1978. A lexical transformation for verbal compounds. Linguistic Inquiry 9(2). 199-260.

Ryder, Mary Ellen. 1994. Ordered chaos: the interpretation of English noun-noun compounds. Berkeley: University of California Press.

Sandra, Dominiek. 1990. On the representation and processing of compound words: Automatic access to constituent morphemes does not occur. The Quarterly Journal of Experimental Psychology Section A 42(3). 529-567. doi: 10.1080/14640749008401236

Sandra, Dominiek. 1994. The morphology of the mental lexicon: Internal word structure viewed from a psycholinguistic perspective. Language and Cognitive Processes 9(3). 227-269. doi: 10.1080/01690969408402119

Scalise, Sergio \& Bisetto, Antonietta. 2009. The classification of compounds. In Lieber, Rochelle \& Štekauer, Pavol (eds.), The Oxford handbook of compounding, 34-53. Oxford: Oxford University Press. doi: 10.1093/oxfordhb/9780199695720.001.0001

Schmidtke, Daniel \& Kuperman, Victor \& Gagné, Christina L. \& Spalding, Thomas L. 2016. Competition between conceptual relations affects compound recognition: the role of entropy. Psychonomic Bulletin \& Review 23(2). 556-570. doi: 10.3758/s13423-0150926-0

Selkirk, Elisabeth O. 1982. The syntax of words. Cambridge, Mass: MIT Press.

Shoben, Edward J. 1991. Predicating and nonpredicating combinations. In Schwanenflugal, Paula J. (ed.), The psychology of word meanings, 117-135. Hillsdale, NJ: Erlbaum.

Siyanova-Chanturia, Anna \& Conklin, Kathy \& Schmitt, Norbert. 2011. Adding more fuel to the fire: An eye-tracking study of idiom processing by native and non-native speakers. Second Language Research 27(2). 251-272. https://doi.org/10.1177/0267658310382068

Szymanek, Bogdan. 2009. IE, Slavonic: Polish. In Lieber, Rochelle \& Štekauer, Pavol (eds.), The Oxford handbook of compounding, 464-477. Oxford: Oxford University Press. doi: 10.1093/oxfordhb/9780199695720.001.0001

Štekauer, Pavol. 2005. Meaning predictability in word formation: novel, context-free naming units. Amsterdam: John Benjamins.

Taft, Marcus \& Forster, Kenneth I. 1975. Lexical storage and retrieval of prefixed words. Journal of Verbal Learning and Verbal Behavior 14(6). 638-647. https://doi.org/10.1016/S0022-5371(75)80051-X 
ten Hacken, Pius. 2009. Early generative approaches. In Lieber, Rochelle \& Štekauer, Pavol (eds.), The Oxford handbook of compounding, 54-77. Oxford: Oxford University Press. doi: 10.1093/oxfordhb/9780199695720.001.0001

Zwitserlood, Pienie. 1994. The role of semantic transparency in the processing and representation of Dutch compounds. Language and Cognitive Processes 9(3). 341-368. https://doi.org/10.1080/01690969408402123

\section{Authors' address:}

University of Zadar, English Department

Obala kralja Petra Krešimira IV. br. 2, 23000 Zadar

E-mail: fmalenica@unizd.hr

zinic.lucija@gmail.com

\section{UTJECAJ LEKSIČKOG I ODNOSNOG USMJERAVANJA NA PROCESIRANJE IMENSKIH SLOŽENICA KOD IZVORNIH I NEIZVORNIH GOVORNIKA ENGLESKOG JEZIKA}

Složenice su česta pojava u engleskom jeziku ali način na koji ih izvorni i neizvorni govornici procesiraju još je predmet lingvističkih rasprava. Dvije vrste čimbenika imaju utjecaj na brzinu prepoznavanja složenica - leksičko usmjeravanje i odnosno usmjeravanje. Prva se vrsta čimbenika ogleda u višoj brzini prepoznavanja u slučajevima kad ciljana i usmjerivačka složenica sadrže zajednički leksem, dok druga vrsta označava podudarnost značenjskog odnosa između modifikatora i glave složenice. Istraživanje koje su proveli Gagné \& Spalding (2004) pokazalo je statistički značajan pozitivan utjecaj odnosnog usmjeravanja na prepoznavanje postojećih složenica, a De Cat i suradnici (2015) navode kako pri procesiranju složenica neizvorni govornici s visokom razinom jezične kompetencije koriste slične strategije kao i izvorni govornici. Cilj je ovog istraživanja replicirati ove rezultate korištenjem zadatka procjene smislenosti postojećih složenica na skupini izvornih i neizvornih govornika, kako bi se dodatno istražili učinci leksičkog i odnosnog usmjeravanja kod ovih dviju skupina ispitanika. Početna je hipoteza da će kod rezultata izvornih govornika biti zabilježeno niže vrijeme reakcije i viša razina točnosti, ali i da će kod obiju skupina biti zabilježen sličan olakšavajući utjecaj različitih vrsta usmjerivača, što rezultati istraživanja i potvrđuju.

Ključne riječi: procesiranje složenica; leksičko usmjeravanje; izvorni i neizvorni govornici; imenske složenice; odnosno usmjeravanje. 
Frane Malenica - Lucija Žinić:

Garden plants and butter knives - the effects of lexical and relation priming on nominal compound processing by native and non-native speakers of English

\section{Appendix}

Table 9. All stimuli used in experimental list 1

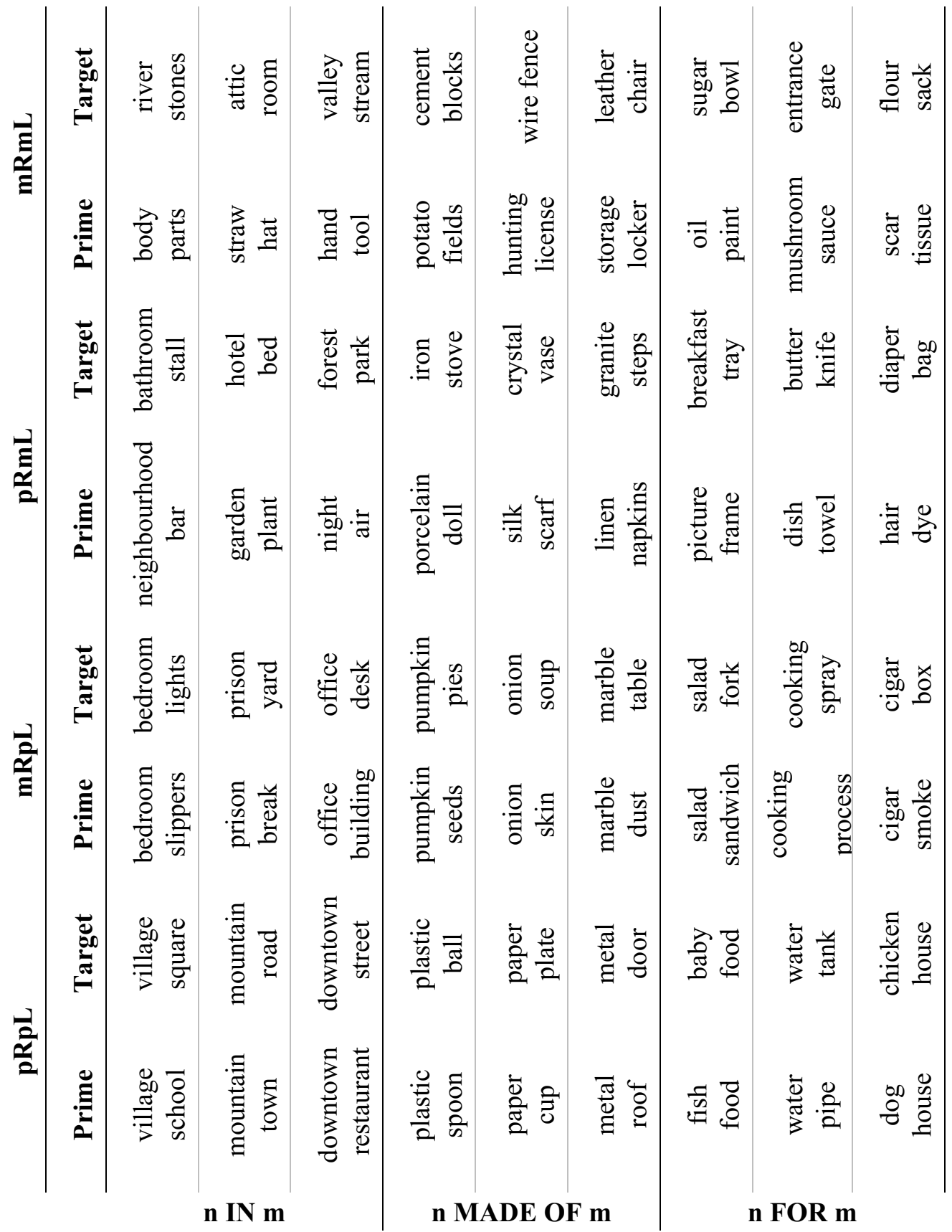


Table 10. All stimuli used in experimental list 2

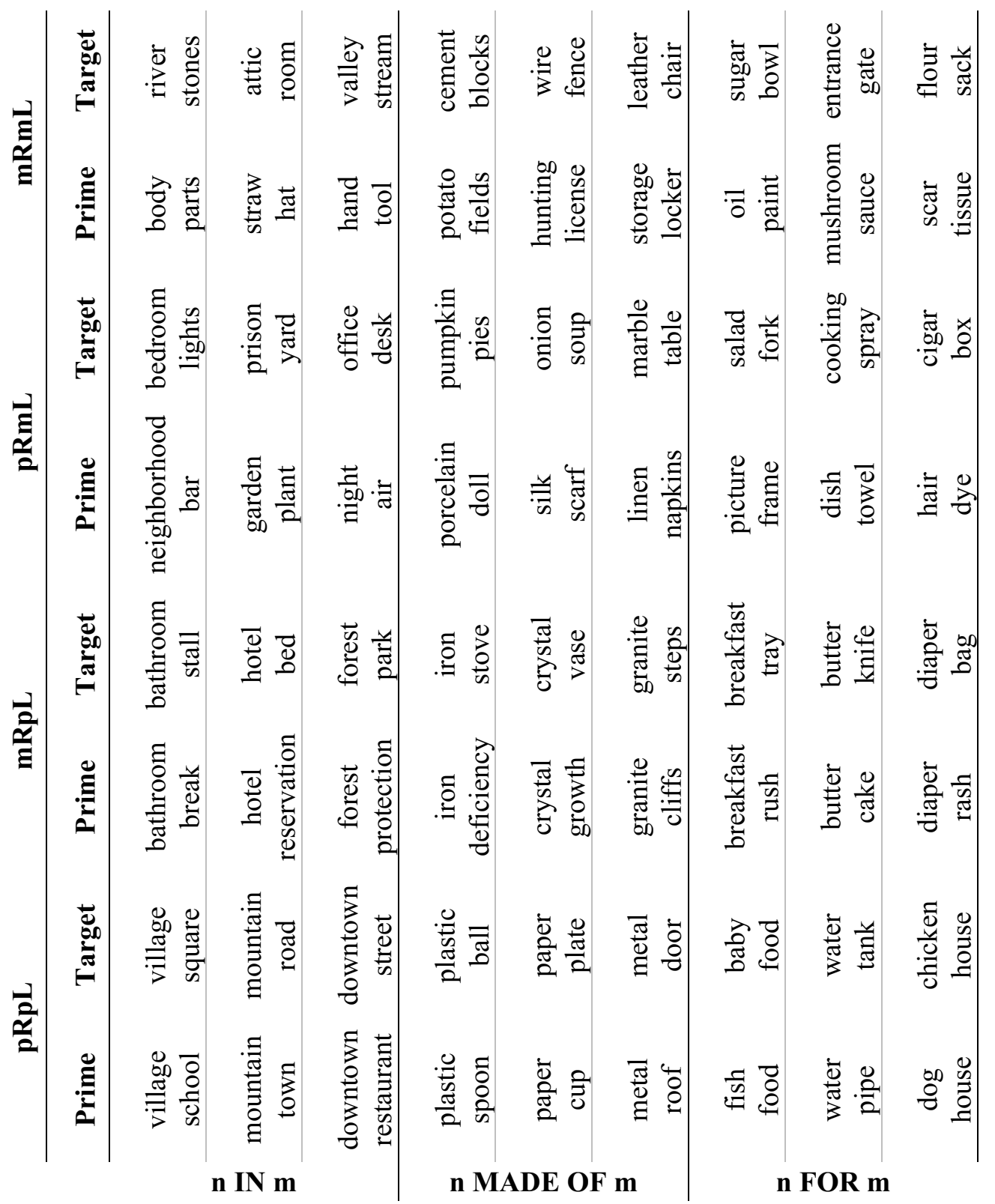


Frane Malenica - Lucija Žinić:

Garden plants and butter knives - the effects of lexical and relation priming on nominal compound processing by native and non-native speakers of English

Table 11. All filler items used in both experimental lists

\begin{tabular}{|c|c|c|c|}
\hline \multicolumn{2}{|c|}{ Filler A } & \multicolumn{2}{|c|}{ Filler B } \\
\hline zilmer chan & shanagest urm & whale branch & wool cloud \\
\hline fringest schmooze & ilky bleast & sparrow deep & celebrity chemical \\
\hline flimmick sood & inger mrack & coffee learn & remedy ranch \\
\hline garnum trab & tonking sump & sand wormy & adolescent broom \\
\hline fush beew & slinker meen & quietly junk & letter worm \\
\hline bool teat & flenging swant & charming hard & factory finger \\
\hline ziel vapest & stangid munst & star puddle & submarine spoil \\
\hline ingus far & rungle schwat & alcohol blink & smell bruise \\
\hline hummzer gumb & ruther jill & honesty leaf & plane cork \\
\hline dangus belp & sint mahwanna & trunk mirror & tile apple \\
\hline ringing fruckle & byrie duned & pencil sleep & train grass \\
\hline fromious sleare & plock tade & volcano pelvis & purple underwhelm \\
\hline mucking slurge & drunger rungy & truck yellow & video meal \\
\hline slurting shmeaze & pist ilkier & white give & wrap college \\
\hline freast birchy & tulf nurtess & line willow & tattoo carpenter \\
\hline shater labine & phuncting mingo & window cowboy & steam slow \\
\hline mundle spast & barcelling junter & mannequin anchor & comedy elude \\
\hline tecking frug & pastering brimb & slowly weight & goat glass \\
\hline stemp just & dalkness ingo & fridge jump & woman algae \\
\hline smaze treng & pasha linst & shelter pink & foam courage \\
\hline prumper zug & fleonesse milt & storm kidney & scissors under \\
\hline hinger pent & tookster neap & binder growl & rubber song \\
\hline hitcher snard & barnger frownsting & lamp beard & cream computer \\
\hline speon clist & staick sluck & & \\
\hline
\end{tabular}

